\title{
An Optimized Duplex Real-Time PCR Tool for Sensitive Detection of the Quarantine Oomycete Plasmopara halstedii in Sunflower Seeds
}

\author{
Renaud Ioos, Céline Fourrier, Véronique Wilson, Kathryn Webb, Jean-Luc Schereffer, and Denis Tourvieille de Labrouhe \\ First, second, and third authors: ANSES, Laboratoire de la Santé des Végétaux, Unité de mycologie, IFR 110, Domaine de Pixérécourt, \\ F-54220 Malzéville, France; fourth author: FERA, 04GA08/09, Sand Hutton, York, YO41 1LZ, United Kingdom; fifth author: ANSES, \\ Laboratoire de la Rage et de la Faune Sauvage de Nancy, Domaine de Pixérécourt; and sixth author: INRA, Plate-Forme IPM, UMR 1095, \\ Domaine de la Crouelle, 234 avenue du Brézet, F-63100 Clermont-Ferrand, France. \\ Accepted for publication 25 May 2012.
}

\begin{abstract}
Ioos, R., Fourrier, C., Wilson, V., Webb, K., Schereffer, J.-L., and Tourvieille de Labrouhe, D. 2012. An optimized duplex real-time PCR tool for sensitive detection of the quarantine oomycete Plasmopara halstedii in sunflower seeds. Phytopathology 102:908-917.

Plasmopara halstedii, the causal agent of downy mildew of sunflower, is an oomycete listed as a quarantine pathogen. This obligate parasite resides in a quiescent state in seeds of sunflower and can be spread from seed production areas to areas of crop production by international seed trade. To prevent the spread or the introduction of potentially new genotypes or fungicide-tolerant strains, an efficient method to detect $P$. hal-

stedii in sunflower seed is required. This work reports the optimization of a real-time detection tool that targets the pathogen within sunflower seeds, and provides statistically validated data for that tool. The tool proved to be specific and inclusive, based on computer simulation and in vitro assessments, and could detect as few as 45 copies of target DNA. A fully optimized DNA extraction protocol was also developed starting from a sample of 1,000 sunflower seeds, and enabled the detection of $<1$ infected seed/1,000 seeds. To ensure reliability of the results, a set of controls was used systematically during the assays, including a plant-specific probe used in a duplex quantitative polymerase chain reaction that enabled the assessment of the quality of each DNA extract.
\end{abstract}

Sunflower downy mildew is caused by the oomycete Plasmopara halstedii (Farl.) Berl. \& De Toni. This pathogen is one of the most significant threats to Helianthus annuus worldwide, and is by now reported on every continent (8). In Europe, it has been observed in sunflower crops, where it causes serious losses (23), since the beginning of the 1960s (16). Despite its widespread distribution, $P$. halstedii is a registered quarantine pest on sunflower seeds in the European Union (1). As many as 35 races of $P$. halstedii are currently described in the world (11). New pathotypes are appearing regularly, and these new virulent forms may bypass resistance in the current sunflower cultivars (23). Another concern is the appearance of fungicide-resistant isolates. Control of the disease often requires fungicide treatment of the seeds; however, metalaxyl-tolerant isolates of $P$. halstedii are now widespread (23). In the European Union (EU), to prevent the introduction and spread of such virulent or fungicide-tolerant $P$. halstedii strains, sunflower seed trade (importation or movement within the Community) is subjected to phytosanitary controls, and the absence of $P$. halstedii in traded seed is officially certified (1).

Enforcement of control by limiting the movement of $P$. halstedii depends on the application of rapid, specific, and sensitive detection tools. There are currently two alternatives proposed in the European Plant Protection Organization (EPPO) diagnostic protocol for the direct detection of $P$. halstedii in seed (3). The first method relies on a bioassay, involving the germination of 400 seeds followed by visual assessment for symptoms of $P$. halstedii, whereas the second method relies on a specific conventional polymerase chain reaction (PCR) test. The time-consuming nature of the bioassay and the risk of false-negative results caused by

Corresponding author: R. Ioos; E-mail address: renaud.ioos@anses.fr

http://dx.doi.org/10.1094/PHYTO-04-12-0068-R

(c) 2012 The American Phytopathological Society low infection levels or nongerminating sporangia or oospores (15) make it unfit for serial analysis of numerous samples. On the other hand, the conventional PCR system can detect any structure of the pathogen, regardless of its biological stage, which is particularly useful for an obligate biotrophic organism that cannot be cultured, such as $P$. halstedii. This conventional PCR method also includes an internal amplification control that enables checking for the presence of PCR-inhibiting compounds, thus preventing false-negative results caused by DNA polymerization inhibition (15).

Over the past decade, real-time PCR technology (qPCR) has been developed for plant pathogen detection in lieu of conventional PCR assays, because it often improves sensitivity and specificity and is quicker (5). Advantages of qPCR have already been exploited for the detection of numerous plant-pathogenic fungi, including quarantine pathogens $(12,19,21,22)$ and other seedborne fungi (14). Reliability of analyses is of paramount importance, due to the economic and environmental consequences of both false-positive results (destruction or rejection of consignment) and false-negative results (introduction of pathogens in disease-free areas).

The objective of this work was to develop a new real-time PCR test targeting $P$. halstedii in seed, in which reaction parameters and the DNA extraction are optimized. This study reports on the validation process proving the robustness of the test and implementation of quality controls to ensure reliability of the results.

\section{MATERIALS AND METHODS}

DNA preparation for oomycete and fungal isolates. All the isolates used in this study are listed in Table 1. P. halstedii isolates were recovered from field samples collected throughout France and other countries, and were propagated on $H$. annuus cotyledons. Following sporulation, the sporangia were collected using a vacuum manifold and immediately transferred into a $2-\mathrm{ml}$ centri- 
fuge tube and kept frozen until DNA extraction. Viable isolates of $P$. halstedii were maintained and manipulated in level 3 biohazard containment facilities, in compliance with EU Directive $\mathrm{CE} / 2008 / 61$ (2). All the other oomycete or fungal isolates were either isolated from sunflower seeds or chosen because of their phylogenetic relatedness with $P$. halstedii. Isolates were cultured with constant shaking in potato dextrose broth (PDB) (Difco, Beckton, Dickinson and Co, Sparks, MD) for 4 to 6 days, after which 50 to $200 \mathrm{mg}$ of fresh mycelium was harvested and transferred into a 2-ml centrifuge tube and kept frozen until DNA extraction. Oomycete or fungal DNA was extracted using a plant DNA extraction kit (DNeasy plant mini kit; Qiagen, Hilden, Germany) following the manufacturer's instructions. DNA concentrations were determined using a Nanodrop ND-1000 spectrometer (Thermo Scientific, Wilmington, Delaware), and

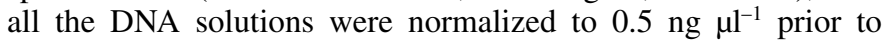
test.

P. halstedii-infected seed material. A severely infected seed (SIS) sample originating from Clermont-Ferrand (France) was manually collected in a parcel where mixed $H$. annuus genotypes were grown from plants showing severe systemic downy mildew symptoms, such as dwarfing. A limited number of flower heads were manually selected according to the severity of the downy mildew symptoms displayed in order to maximize the potential biomass of $P$. halstedii. The SIS sample was ground for $1 \mathrm{~min}$ in a 125-ml sterilized glass bowl using a Microtron MB 550 mixer mill (Kinematica, Lucerne, Switzerland). The SIS powder was used to produce a series of calibrated contaminated seed samples. Aliquots of 1,000 seeds from a healthy seed lot of 'Helios RM' were obtained. The thousand-kernel weight was determined and, based on this value $(54.0 \pm 0.2 \mathrm{~g})$, powder aliquots of SIS representing an equivalent weight of $1,5,10$, and 20 Helios RM infected seeds were added to 999, 995, 990, and 980 Helios RM seeds, respectively. Three replicates of healthy Helios RM controls (1,000 healthy seeds) were also prepared. Three replicates were prepared for each contamination level. The 15 seed samples were processed following the DNA extraction optimization chart presented in Figure 1. Briefly, each of these 15 seed samples was first ground dry for $1 \mathrm{~min}$ with the mixer mill; then, 12 subsamples of $\approx 500 \mu \mathrm{l}$ (corresponding to $190 \pm 20 \mathrm{mg}$ ) were collected using a sterile spatula and transferred aseptically in individual sterile 2-ml microcentrifuge tubes. The rest of the powder was kept in the glass bowl and ground again for $10 \mathrm{~s}$ with $50 \mathrm{ml}$ of TNE buffer $(100 \mathrm{mM}$ Tris; $2.0 \mathrm{M} \mathrm{NaCl}$; and $10 \mathrm{mM}$

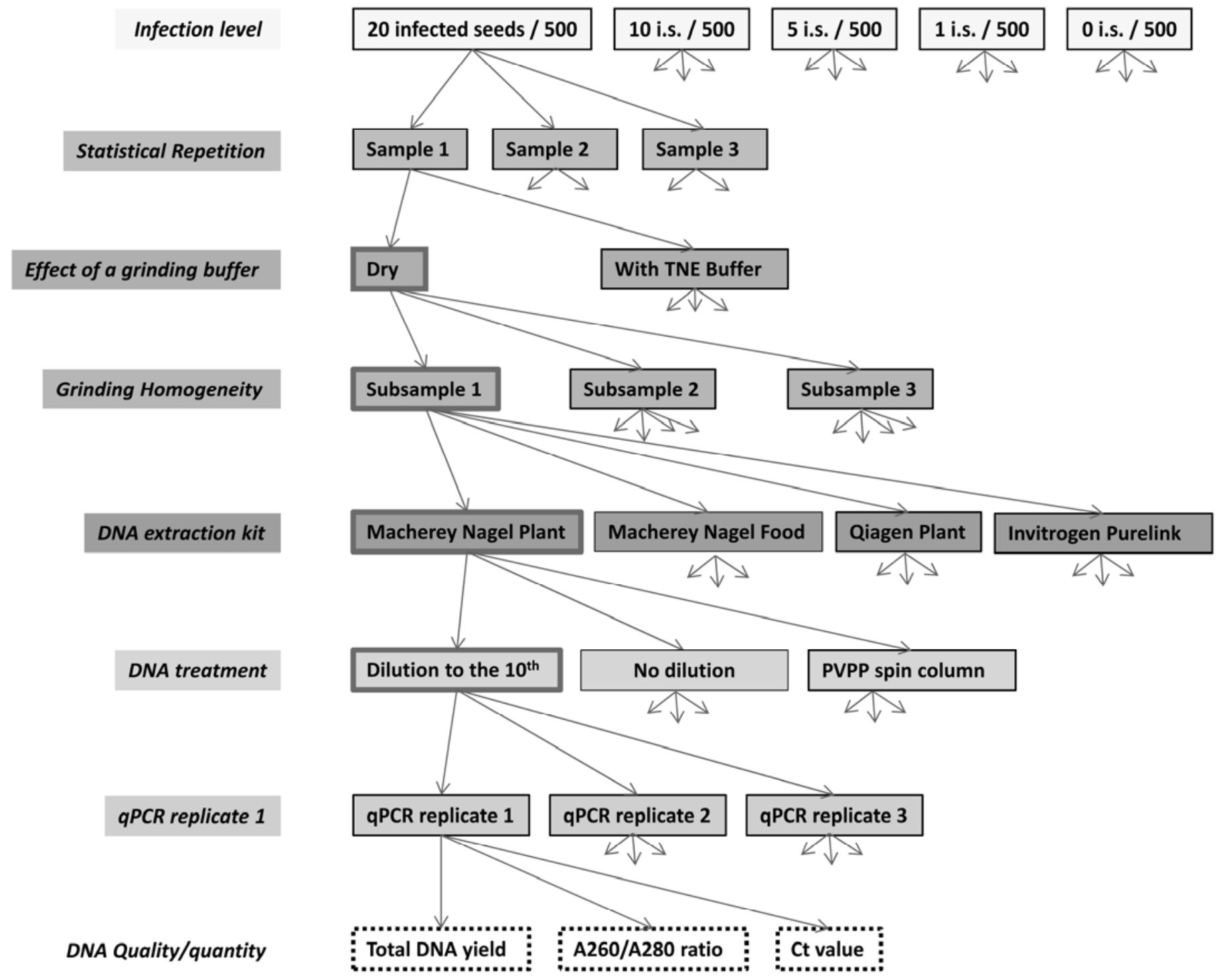

Fig. 1. DNA extraction optimization chart followed in this study in order to develop a sensitive detection test for Plasmopara halstedii. The effect of each parameter on the cycle threshold $(\mathrm{Ct})$ value, total DNA yield, or DNA purity was assessed separately or in combination with others by analysis of variance. Significance of the effects was evaluated using Fisher's least significant difference and the best option is boxed with a bold line when significant. Tiny arrows under boxes indicate that the same treatment was followed for each value. 
EDTA, pH 7.4). Another 12 subsamples of macerate $(\approx 600 \mu \mathrm{l})$ were collected using a micropipette and transferred aseptically in individual sterile $2-\mathrm{ml}$ microcentrifuge tubes. To prevent crosscontamination between samples, the mixer mill bowls were systematically sterilized after use by soaking and cleaning in a freshly prepared $2 \%$ sodium hypochlorite solution.

For each replicate of each contamination level, three microtubes containing $500 \mu \mathrm{l}$ of $H$. annuus seed dry powder and three microtubes containing $600 \mu \mathrm{l}$ of $H$. annuus seed macerate were used as starting material for total DNA extraction. Total DNA extraction was carried out using four commercial DNA extraction kits according to the manufacturer's instructions: NucleoSpin Plant II with PL1 lysis buffer (Macherey-Nagel, Düren, Germany), NucleoSpin Food (Macherey-Nagel), DNeasy plant mini kit (Qiagen), and PureLink Genomic Plant DNA (Invitrogen, Carlsbad, CA). Each DNA extract $(100 \mu \mathrm{l})$ was tested in triplicate by duplex qPCR (i) directly, (ii) after a polyvinyl-polypyrrolidone (PVPP) spin-column purification following the protocol described by Cullen and Hirsch (9), and (iii) after a 10-fold dilution in $1 \times$ Tris-EDTA buffer (Sigma-Aldrich, Lyon, France). Total DNA yield, DNA purity ratio (absorbance at $280 / 260 \mathrm{~nm}\left[\mathrm{~A}_{280} / \mathrm{A}_{260}\right]$ ), and mean cycle threshold $(\mathrm{Ct})$ values were reported and the effect of each option during the DNA extraction step was assessed using XLSTAT (version 2012.1.01; Addinsoft, Paris) by one-way analysis of variance (ANOVA). Differences between mean values for each variable were assessed using Fisher's least significant difference test. In all combinations, mean $\mathrm{Ct}$ values were calculated such that all values of $\mathrm{Ct}>40$ were taken as equal to 40 .

Samples of $H$. annuus leaves or seeds were also collected in different fields from four different countries and their DNA was tested by the qPCR test developed in this study to confirm the experimental specificity of the assay (Table 2).

Design of primers and hydrolysis probes. The large-subunit (LSU) ribosomal DNA sequence has been used successfully to conduct phylogenetic analyses on downy mildew pathogens, including the genus Plasmopara $(18,24)$. The LSU DNA is repeated up to 100 to 200 times within a single nucleus (25), which makes it an appropriate target area for developing sensitive detection tools. Partial LSU sequences for 26 isolates of Plasmopara spp. phylogenetically close to $P$. halstedii and 7 isolates of $P$. halstedii representing different geographical origins were retrieved

TABLE 1. Oomycetes and fungal isolates used in this study

\begin{tabular}{|c|c|c|c|c|c|c|c|}
\hline Isolate & Reference & Race $^{\mathrm{u}}$ & Host & Origin & $\begin{array}{c}\text { Collection } \\
\text { year }\end{array}$ & Source $^{v}$ & $\begin{array}{c}\text { qPHAL } \\
\text { qPCR test }{ }^{w}\end{array}$ \\
\hline \multirow[t]{40}{*}{ Plasmopara halstedii } & Pv 091 & 710 & Helianthus annuus leaf & France & 2009 & INRA & $20.16(0.04)$ \\
\hline & Pv 09.6 & 703 & H. annuus leaf & France & 2009 & INRA & $13.97(0.06)$ \\
\hline & Pv 09.7 & 710 & H. annuus leaf & France & 2009 & INRA & $16.21(0.06)$ \\
\hline & Pv 09.8 & 703 & H. annuus leaf & France & 2009 & INRA & $16.11(0.01)$ \\
\hline & Pv 09.9 & 334 & H. annuus leaf & France & 2009 & INRA & $14.77(0.44)$ \\
\hline & Pv 0910 & 334 & H. annuus leaf & France & 2009 & INRA & $14.98(0.05)$ \\
\hline & Pv 0911 & 334 & H. annuus leaf & France & 2009 & INRA & $13.87(0.07)$ \\
\hline & Pv 0912 & 334 & H. annuus leaf & France & 2009 & INRA & $10.54(0.19)$ \\
\hline & Pv 09.13 & 334 & H. annuus leaf & France & 2009 & INRA & $10.71(0.09)$ \\
\hline & Pv 09.14 & 334 & H. annuus leaf & France & 2009 & INRA & $10.88(0.06)$ \\
\hline & Pv 09.15 & 710 & H. annuus leaf & France & 2009 & INRA & $11.05(0.02)$ \\
\hline & Pv 09.16 & 710 & H. annuus leaf & France & 2009 & INRA & $10.96(0.10)$ \\
\hline & Pv 0918 & 304 & H. annuus leaf & France & 2009 & INRA & $11.19(0.06)$ \\
\hline & Pv 0919 & 710 & H. annuus leaf & France & 2009 & INRA & $11.03(0.05)$ \\
\hline & Pv 0920 & 714 & H. annuus leaf & France & 2009 & INRA & $11.52(0.36)$ \\
\hline & Pv 0921 & 714 & H. annuus leaf & France & 2009 & INRA & $11.72(0.14)$ \\
\hline & Pv 09.22 & 710 & H. annuus leaf & France & 2009 & INRA & $10.90(0.08)$ \\
\hline & Pv 09.23 & 304 & H. annuus leaf & France & 2009 & INRA & $11.84(0.03)$ \\
\hline & Pv 09.24 & $707+714+717^{x}$ & H. annuus leaf & France & 2009 & INRA & $12.69(0.08)$ \\
\hline & Pv 09.25 & 714 & H. annuus leaf & France & 2009 & INRA & $11.79(0.05)$ \\
\hline & Pv 09.26 & 714 & H. annuus leaf & France & 2009 & INRA & $13.06(0.10)$ \\
\hline & Pv 0927 & 714 & H. annuus leaf & France & 2009 & INRA & $12.70(0.04)$ \\
\hline & Pv 0928 & 703 & H. annuus leaf & France & 2009 & INRA & $11.70(0.07)$ \\
\hline & Pv 0929 & 714 & H. annuus leaf & France & 2009 & INRA & $10.98(0.03)$ \\
\hline & Pv 0930 & 304 & H. annuus leaf & France & 2009 & INRA & $11.91(0.06)$ \\
\hline & Pv 09.31 & 714 & H. annuus leaf & France & 2009 & INRA & $10.12(0.02)$ \\
\hline & Pv 09.33 & 334 & H. annuus leaf & France & 2009 & INRA & $11.00(0.06)$ \\
\hline & Pv 09.34 & 774 & H. annuus leaf & France & 2009 & INRA & $13.33(0.17)$ \\
\hline & Pv 09.35 & $334+714^{x}$ & H. annuus leaf & France & 2009 & INRA & $10.99(0.06)$ \\
\hline & SA 06 & 707 & H. annuus leaf & France & 2009 & INRA & $12.21(0.07)$ \\
\hline & VF 05 & 707 & H. annuus leaf & France & 2009 & INRA & $12.32(0.09)$ \\
\hline & VN 04 & 707 & H. annuus leaf & France & 2009 & INRA & $13.13(0.10)$ \\
\hline & DUG 02 & 304 & H. annuus leaf & France & 2009 & INRA & $11.86(0.02)$ \\
\hline & BA 01 & 703 & H. annuus leaf & France & 2009 & INRA & $12.25(0.21)$ \\
\hline & BD 02 & 707 & H. annuus leaf & France & 2009 & INRA & $11.73(0.11)$ \\
\hline & BD 03 & 704 & H. annuus leaf & France & 2009 & INRA & $12.09(0.05)$ \\
\hline & RTH 03 & 300 & H. annuus leaf & France & 2009 & INRA & $12.34(0.08)$ \\
\hline & DG01 & 304 & H. annuus leaf & France & 2009 & INRA & $11.08(0.04)$ \\
\hline & INRA 100 & 100 & H. annuus leaf & France & 2000 & INRA & $10.99(0.06)$ \\
\hline & INRA 710 & 710 & H. annuus leaf & France & 2002 & INRA & $11.63(0.06)$ \\
\hline
\end{tabular}

u Races were determined according to Tourvieille de Labrouhe (20) ; n.d. = not determined; N/A = not applicable.

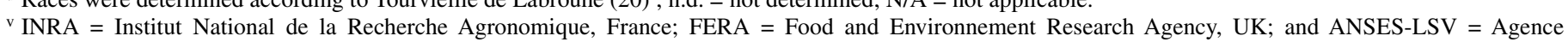
Nationale de Sécurité Sanitaire, Laboratoire de la Santé des Végétaux, France.

${ }^{\mathrm{w}} \mathrm{qPCR}=$ quantitative polymerase chain reaction. Mean cycle threshold $(\mathrm{Ct})$ values and corresponding standard deviation (in parentheses) are indicated.

${ }^{x}$ Mixture of different races.

y T. Gulya, United States.

z World Wide Phytophthora Collection (Mike Coffey, United States). 
from GenBank. All the sequences were analyzed and compared by multiple alignments using CLUSTALW (http://npsa-pbil.ibcp.fr/ cgi-bin/npsa_automat.pl?page=/NPSA/npsa_clustalwan.html). A selection of forward primer-reverse primer-probe combinations specific for $P$. halstedii were designed from several target polymorphic regions within the LSU, using Primer 3 online software (http://frodo.wi.mit.edu/primer3/), and then manually tuned to target $P$. halstedii-specific polymorphic sites. Their respective melting temperatures $(\mathrm{Tm})$ and potential secondary structures were evaluated in silico using Beacon Designer software (Premier Biosoft, Palo Alto, CA) in order to select suitable forward and reverse primer combinations. Primers were also designed in a way to amplify a very short PCR fragment, because they amplify more efficiently and are more tolerant of reaction conditions (7). These forward and reverse primer combinations were then evaluated in vitro by real-time PCR, with SYBR green intercalating dye to assess their sensitivity and their proneness to self- or interhybridization. The primers were tested with serial dilutions of total DNA extracted from sporangia produced by the isolate PV 09-7. The primer pair combining the lowest tendency to form secondary structures and the best sensitivity was retained for further development of $P$. halstedii hydrolysis probe (HP). Retained primers and probe also fulfilled the technical and thermodynamic requirements for a primer-hydrolysis probe combination for real-time PCR according to Bustin (7). Primer and probe sequences, and probe reporter and quencher dyes, are shown in Table 3. A universal primer pair (18S uni-F/-R) and an HP (18S uni-P) (14) were also used in this study to target a region of the $18 \mathrm{~S}$ rDNA that is highly conserved throughout a wide range of eukaryotic organisms, including plants, and showed $100 \%$ in silico annealing with $H$. annuus $18 \mathrm{~S}$ rDNA target regions. These primers and probe were selected in order to check the quality of the DNA extracted from $H$. annuus seeds and to screen out falsenegative results that could potentially be caused by inhibition or DNA shearing (26). The reporting dyes of the two HPs were selected to have distinctive fluorescence emission wavelengths in order to avoid any overlapping fluorescence spectra, which made their simultaneous use in a single PCR tube possible (Table 3). All primers and probes were custom synthesized by Eurogentec (Seraing, Belgium).

Implementation of quality controls. The PCR product, amplified from $P$. halstedii genomic DNA using primer pair qPHAL-F/-R

TABLE 1. (continued from preceding page)

\begin{tabular}{|c|c|c|c|c|c|c|c|}
\hline Isolate & Reference & Race $^{\mathrm{u}}$ & Host & Origin & $\begin{array}{c}\text { Collection } \\
\text { year }\end{array}$ & Source $^{v}$ & $\begin{array}{c}\text { qPHAL } \\
\text { qPCR test }{ }^{\mathrm{w}}\end{array}$ \\
\hline \multicolumn{8}{|l|}{ Plasmopara halstedii } \\
\hline & DU1035 & 710 & H. annuus leaf & France & 2004 & INRA & $10.89(0.08)$ \\
\hline & INRA 700 & 700 & H. annuus leaf & France & 2004 & INRA & $11.87(0.11)$ \\
\hline & INRA 314 & 314 & H. annuus leaf & France & 2003 & INRA & $11.62(0.10)$ \\
\hline & 330 USA & 330 & H. annuus leaf & United States & 2004 & INRA & $11.46(0.24)$ \\
\hline & $\mathrm{R} 300$ & 300 & H. annuus leaf & United States & 2004 & INRA & $11.68(0.06)$ \\
\hline & 2555 & n.d. & H. annuus leaf & Unknown & 1995 & FERA $^{y}$ & $21.55(0.01)$ \\
\hline & 1962 & n.d. & H. annuus leaf & United States & 1990 & FERA $^{y}$ & $18.24(0.13)$ \\
\hline & 1963 & n.d. & H. annuus leaf & United States & 1990 & FERA $^{y}$ & $16.49(1.07)$ \\
\hline & 1963 & n.d. & H. annuus leaf & United States & 1991 & FERA $^{y}$ & $15.11(1.53)$ \\
\hline & 2674 & n.d. & H. annuus leaf & Unknown & 1996 & FERA $^{y}$ & $30.33(1.36)$ \\
\hline & 2847 & n.d. & H. annuus leaf & United States & 1999 & FERA $^{y}$ & $18.63(0.23)$ \\
\hline Peronospora sordida & $\mathrm{AB}$ fdc & N/A & Bacopa sp. & Germany & 2005 & FERA & $\mathrm{Ct}>40$ \\
\hline Erysiphe heraclei & 20900276 & N/A & Petroselinum crispum & Unknown & 2009 & FERA & $\mathrm{Ct}>40$ \\
\hline Peronospora chenopodii & 21013596 & N/A & Chenopodium sp. & United Kingdom & 2010 & FERA & $\mathrm{Ct}>40$ \\
\hline P. belbahrii & 21018488 & N/A & Ocimum basilicum & United Kingdom & 2010 & FERA & $\mathrm{Ct}>40$ \\
\hline P. violae & PC/4441 & N/A & Primula sp. & Unknown & 2006 & FERA & $\mathrm{Ct}>40$ \\
\hline Plasmopara obducens & $21 / 5 / 07$ & N/A & Impatiens sp. & United Kingdom & 2007 & FERA & $\mathrm{Ct}>40$ \\
\hline Plasmopara obducens & GT IDM & N/A & Impatiens sp. & Kenya & 2007 & FERA & $\mathrm{Ct}>40$ \\
\hline Peronospora violae & $5 / 1 / 07$ & N/A & Viola sp. & United Kingdom & 2007 & FERA & $\mathrm{Ct}>40$ \\
\hline P. violae & PDM T14/2 & N/A & Viola sp. & United Kingdom & 2008 & FERA & $\mathrm{Ct}>40$ \\
\hline Phytophthora pseudotsugae & P10339 & N/A & Pseudotsuga menziesii & Unknown & 2003 & FERA $^{z}$ & $\mathrm{Ct}>40$ \\
\hline Phytophthora hedraiandra & P11056 & N/A & Rhododendron sp. & Unknown & 2006 & FERA $^{\mathrm{z}}$ & $\mathrm{Ct}>40$ \\
\hline P. cactorum & P6475 & N/A & Fragaria $\times$ ananassa & Unknown & Unknown & FERA $^{\mathrm{z}}$ & $\mathrm{Ct}>40$ \\
\hline P. cactorum & $\operatorname{cc} 2151$ & N/A & Photinia sp. & Italy & 2004 & FERA & $\mathrm{Ct}>40$ \\
\hline P. citrophthora & $\mathrm{PH} 2$ & N/A & Chamaecyparis sp. & France & 2003 & ANSES, LSV & $\mathrm{Ct}>40$ \\
\hline P. cryptogea & $\mathrm{PH} 3$ & N/A & Taxus sp. & France & 2003 & ANSES, LSV & $\mathrm{Ct}>40$ \\
\hline P. megasperma sl & $\mathrm{PH} 7$ & N/A & Soil from oak stand & France & 2003 & ANSES, LSV & $\mathrm{Ct}>40$ \\
\hline P. cactorum & $\mathrm{PH} 22$ & N/A & Viola sp. & France & 2003 & ANSES, LSV & $\mathrm{Ct}>40$ \\
\hline P. cambivora & $\mathrm{PH} 26$ & N/A & Soil from oak stand & France & 2003 & ANSES, LSV & $\mathrm{Ct}>40$ \\
\hline P. citricola & PH38 & N/A & Soil from Alnus stand & France & 2003 & ANSES, LSV & $\mathrm{Ct}>40$ \\
\hline P. gonapodyides & PH41 & N/A & Soil from Alnus stand & France & 2003 & ANSES, LSV & $\mathrm{Ct}>40$ \\
\hline Pythium irregulare & PY1 & N/A & Unknown & France & 2003 & ANSES, LSV & $\mathrm{Ct}>40$ \\
\hline P. violae & PY11 & N/A & Unknown & France & 2003 & ANSES, LSV & $\mathrm{Ct}>40$ \\
\hline P. vexans & PY14 & N/A & Citrus reticulata & France & 2003 & ANSES, LSV & $\mathrm{Ct}>40$ \\
\hline Candida albicans & LNPV1 & N/A & H. annuus seeds & France & 2009 & ANSES, LSV & $\mathrm{Ct}>40$ \\
\hline Epicoccum nigrum & LNPV2 & N/A & H. annuus seeds & France & 2009 & ANSES, LSV & $\mathrm{Ct}>40$ \\
\hline Penicillium sp. & LNPV3 & N/A & H. annuus seeds & France & 2009 & ANSES, LSV & $\mathrm{Ct}>40$ \\
\hline Rhizopus orizae & LNPV4 & N/A & H. annuus seeds & France & 2009 & ANSES, LSV & $\mathrm{Ct}>40$ \\
\hline Aspergillus sp. & LNPV5 & N/A & H. annuus seeds & France & 2009 & ANSES, LSV & $\mathrm{Ct}>40$ \\
\hline Cladosporium cladosporioides & LNPV6 & N/A & H. annuus seeds & France & 2009 & ANSES, LSV & $\mathrm{Ct}>40$ \\
\hline Alternaria $\mathrm{sp} 1$ & LNPV7 & N/A & H. annuus seeds & France & 2009 & ANSES, LSV & $\mathrm{Ct}>40$ \\
\hline Alternaria sp2 & LNPV8 & N/A & H. annuus seeds & France & 2009 & ANSES, LSV & $\mathrm{Ct}>40$ \\
\hline Penicillium sp. & LNPV9 & N/A & H. annuus seeds & France & 2009 & ANSES, LSV & $\mathrm{Ct}>40$ \\
\hline Fusarium sp. & LNPV10 & N/A & H. annuus seeds & France & 2009 & ANSES, LSV & $\mathrm{Ct}>40$ \\
\hline Alternaria $\mathrm{sp} 3$ & LNPV12 & N/A & H. annuus seeds & France & 2009 & ANSES, LSV & $\mathrm{Ct}>40$ \\
\hline Alternaria $\mathrm{sp} 1$ & LNPV14 & N/A & H. annuus seeds & France & 2009 & ANSES, LSV & $\mathrm{Ct}>40$ \\
\hline Phomopsis helianthi & LNPV19 & N/A & H. annuus stem & France & 2009 & ANSES, LSV & $\mathrm{Ct}>40$ \\
\hline
\end{tabular}


(94 bp), was inserted into a pCR4-TOPO vector (Invitrogen), which was used to transform chemically competent TOP10 cells (Invitrogen), according to the manufacturer's instructions. The bacterial clones were then subcultured overnight and the plasmids were purified using a Nucleospin Plasmid kit (Macherey-Nagel). Based on the sequences of pCR4-TOPO vector and qPHAL-F/-R amplicon, the molecular weight of the individual subcloned plasmid could be determined and the corresponding purified plasmid solution could be calibrated (i.e., the number of target plasmid copies [pcs] per microliter was calculated). A calibrated stock positive control solution and a serial dilution thereof were prepared and stored at $-20^{\circ} \mathrm{C}$ until use.

All PCR analyses were carried out using standard procedures to avoid cross-contamination of DNA. Non-template controls were systematically included in triplicate to check the absence of contamination in all reactions of conventional or real-time PCR.

Prior to routine analysis, a threshold $18 \mathrm{~S} \mathrm{Ct}$ value $\left(\mathrm{Ct}_{18 \mathrm{~S}}\right)$ was experimentally determined for the duplex real-time assay, in order to be used as a basal reference to assess the quality of each DNA solution extracted from $H$. annuus seed samples. The $\mathrm{Ct}_{18 \mathrm{~s}}$ was set as the maximum acceptable mean $\mathrm{Ct}$ value for a DNA sample to be considered as amplifiable (i.e., containing a sufficient amount of DNA) and for which no significant PCR inhibition affected the results. In other words, when a DNA sample yielded a mean $18 \mathrm{~S} \mathrm{Ct}$ value below or equal to $\mathrm{Ct}_{18 \mathrm{~S}}$, total DNA was correctly extracted and a sufficiently low quantity of inhibiting compounds was co-extracted (13). The $\mathrm{Ct}_{18 \mathrm{~s}}$ value was determined by computing the mean and standard deviation for all the $18 \mathrm{~S}$ uni $\mathrm{Ct}$ values obtained with DNA from a series of healthy or naturally and artificially infected seed samples, extracted following the optimized DNA extraction protocol developed in this study (see Results section). The DNA extracts from contaminated seed samples yielded positive results with qPHAL-F/-R/-P, meaning that DNA was amplifiable, and the corresponding $18 \mathrm{~S}$ uni mean $\mathrm{Ct}$ value must have been within the acceptable range. Each DNA from a healthy sample and its 10-fold dilution were tested by the duplex qPCR. A mean $\mathrm{Ct}$ value difference of $\leq 3.3$ between undiluted and diluted sample DNA showed that there was no significant inhibition of the real-time PCR reaction.

Optimization of the real-time PCR conditions. Different real-time PCR conditions were tested in order to maximize sensitivity while retaining specificity toward the target. Different parameters were statistically evaluated and optimized to increase sensitivity (i.e., mean $\mathrm{Ct}$ value of the duplex qPCR test): qPHAL-

TABLE 2. Helianthus annuus samples used in this study

\begin{tabular}{|c|c|c|c|c|c|c|c|}
\hline \multirow[b]{2}{*}{ Reference } & \multirow[b]{2}{*}{ Tissue } & \multirow[b]{2}{*}{ Origin } & \multirow[b]{2}{*}{ Field condition ${ }^{\mathrm{W}}$} & \multirow[b]{2}{*}{ Collection year } & \multirow[b]{2}{*}{ Source ${ }^{\mathrm{x}}$} & \multicolumn{2}{|c|}{ qPCR test ${ }^{\mathrm{y}}$} \\
\hline & & & & & & qPHAL & $18 \mathrm{~S}$ uni \\
\hline SIS & Seed & France & Symptomatic & 2009 & INRA & $15.37(0.11)$ & $12.58(0.20)$ \\
\hline Helios RM & Seed & France & Nonsymptomatic & 2009 & INRA & $\mathrm{Ct}>40$ & $13.23(0.12)$ \\
\hline P. hal 1 & Seed & United Kingdom & Nonsymptomatic & 2010 & FERA & $\mathrm{Ct}>40$ & $14.45(0.21)$ \\
\hline P. hal 2 & Seed & United Kingdom & Nonsymptomatic & 2010 & FERA & $\mathrm{Ct}>40$ & $13.79(0.43)$ \\
\hline $3 \mathrm{KC}^{\mathrm{z}}$ & Seed & Hungary & Symptomatic & 2009 & FERA & $18.20(0.10)$ & $12.07(0.34)$ \\
\hline P. hal 4 & Seed & Hungary & Nonsymptomatic & 2010 & FERA & $\mathrm{Ct}>40$ & $11.45(0.31)$ \\
\hline P. hal 5 & Seed & Hungary & Nonsymptomatic & 2010 & FERA & $\mathrm{Ct}>40$ & $10.79(0.23)$ \\
\hline P. hal 6 21023775/1 & Seed & United Kingdom & Symptomatic & 2010 & FERA & $\mathrm{Ct}>40$ & $18.31(0.44)$ \\
\hline P. hal $721023775 / 2$ & Seed & United Kingdom & Symptomatic & 2010 & FERA & $\mathrm{Ct}>40$ & $11.88(0.46)$ \\
\hline $1 \mathrm{~GB}$ & Seed & France & Symptomatic & 2009 & INRA & $18.02(0.33)$ & $12.90(0.15)$ \\
\hline $02 \mathrm{FU}^{\mathrm{z}}$ & Seed & France & Symptomatic & 2009 & INRA & $15.57(0.12)$ & $10.10(0.47)$ \\
\hline 3 PSU7 & Seed & France & Symptomatic & 2009 & INRA & $15.86(0.09)$ & $11.43(0.09)$ \\
\hline 4 PR56 & Seed & France & Symptomatic & 2009 & INRA & $16.06(0.04)$ & $10.71(0.19)$ \\
\hline $5 \operatorname{mix}$ & Seed & France & Symptomatic & 2009 & INRA & $20.11(0.03)$ & $10.78(0.23)$ \\
\hline $9 \mathrm{~GB} \times \mathrm{PR} 56$ & Seed & France & Symptomatic & 2009 & INRA & $17.00(0.03)$ & $9.25(0.15)$ \\
\hline $14 \mathrm{KC} \mathrm{DM}^{\mathrm{z}}$ & Infected leaf & United States & Symptomatic & 2010 & USDA & $10.12(0.27)$ & $11.31(0.23)$ \\
\hline P. hal 15 DM157 & Infected leaf & United States & Symptomatic & 2010 & USDA & $10.92(0.08)$ & $13.97(0.71)$ \\
\hline P. hal 16 DM104 & Infected leaf & United States & Symptomatic & 2010 & USDA & $10.97(0.09)$ & $13.34(0.59)$ \\
\hline P. hal 17 DM46 & Infected leaf & United States & Symptomatic & 2010 & USDA & $10.85(0.12)$ & $14.22(1.37)$ \\
\hline P. hal 18 & Infected leaf & United States & Symptomatic & Unknown & USDA & $10.80(0.14)$ & $13.20(0.51)$ \\
\hline UK POS $21023776^{z}$ & Infected leaf & United Kingdom & symptomatic & 2010 & FERA & $18.20(0.10)$ & $28.95(0.42)$ \\
\hline
\end{tabular}

w Presence or absence of typical downy mildew symptoms in the field

${ }^{\mathrm{x}}$ INRA = Institut National de la Recherche Agronomique, France; FERA = Food and Environnement Research Agency, UK; and USDA = United States Department of Agriculture.

${ }^{y}$ $\mathrm{PCCR}=$ quantitative polymerase chain reaction. Mean cycle threshold $(\mathrm{Ct})$ values and standard deviation (in parentheses) are given for each primers/probe combination run in a duplex assay.

${ }^{\mathrm{z}} \mathrm{H}$. annuиs DNA samples whose qPCR amplicon was sequenced and deposited in GenBank.

TABLE 3. Primers and hydrolysis probes designed and/or tested in this study

\begin{tabular}{|c|c|c|c|c|c|c|}
\hline $\begin{array}{l}\text { Target, } \\
\text { primer or probe }\end{array}$ & Sequence $\left(5^{\prime}-3^{\prime}\right)$ & $\underset{\left({ }^{\circ} \mathrm{C}\right)^{\mathrm{W}}}{\mathrm{Tm}}$ & Test (reference) $)^{\mathrm{x}}$ & DNA region & Position $^{\mathrm{y}}$ & $\begin{array}{l}\text { Product } \\
\text { size (bp) }\end{array}$ \\
\hline \multicolumn{7}{|c|}{ Plasmopara halstedii } \\
\hline qPHAL-F & TTCCAGTGTCTATAATCCGTGGT & 59.8 & PCR (this study) & 28S rDNA & $355-378$ & 94 \\
\hline qPHAL-R & GCACATACGCCGAGCGTA & 62.0 & $\ldots$ & $\ldots$ & $431-448$ & $\ldots$ \\
\hline qPHAL-P & FAM-TCGGCGAGCGTGTGCGTGT-BHQ1 & 72.1 & $\ldots$ & $\ldots$ & $386-405$ & $\ldots$ \\
\hline \multicolumn{7}{|c|}{ Helianthus annuиs } \\
\hline $18 \mathrm{~S}$ uni-F & GCAAGGCTGAAACTTAAAGGAA & 59.9 & PCR (13) & 18S rDNA & $1,105-1,126$ & 150 \\
\hline $18 \mathrm{~S}$ uni-R & CCACCACCCATAGAATCAAGA & 59.8 & $\ldots$ & $\ldots$ & $1,234-1,254$ & $\ldots$ \\
\hline 18S uni-P & JOE-ACGGAAGGGCACCACCAGGAGT-BHQ1 & 70.3 & $\ldots$ & $\ldots$ & $1,130-1,151$ & $\ldots$ \\
\hline
\end{tabular}

${ }^{w}$ Melting temperature determined by Primer 3 software according to Breslauer et al. (6).

${ }^{x} \mathrm{PCR}=$ real-time polymerase chain reaction.

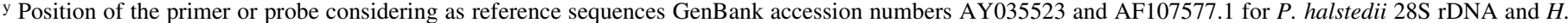
annuus $18 \mathrm{~S}$ rDNA, respectively.

z Black Hole Quencher 1, registered trademark of Biosearch Technologies, Inc. 
$\mathrm{F} /-\mathrm{R} / \mathrm{P}$ concentration ratios $(0.05,0.1,0.2$, or $0.3 \mu \mathrm{M}$ for each molecule), $\mathrm{MgCl}_{2}$ concentration $(4,5$, or $6 \mathrm{mM})$, use of bovine serum albumin (BSA) $\left(0.6 \mu \mathrm{g} \mu \mathrm{l}^{-1}\right.$ or none), hybridization temperature $\left(60,62\right.$, and $\left.65^{\circ} \mathrm{C}\right)$ and denaturation/polymerization PCR patterns $(5 / 45,10 / 45,15 / 45$, and $15 / 15 \mathrm{~s})$. All the parameters were assessed with six replicates (three for the primer-probe concentration assessment) of plasmid DNA standards diluted in a background of $H$. annuus seed DNA set at $228,2.28 \times 10^{3}$, and

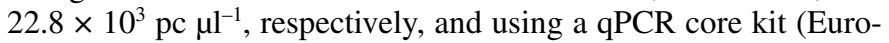
gentec) as a reference.

Four different brands and types of commercial qPCR master mix (Eurogentec core kit no ROX, Qiagen QuantiTect Multiplex PCR, Eurogentec qPCR mastermix no ROX, and Invitrogen TaqMan master mix) were then tested, using the best value selected for each of the parameters listed above. Finally, the specificity of the duplex qPCR optimized for sensitivity was verified. DNA extracts were prepared from a worldwide collection of 54 P. halstedii isolates, including different races and geographical origin, fungi commonly isolated from soil and sunflower seed (Table 1). All the DNA extracts were normalized to

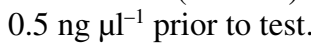

The optimized duplex qPCR conditions retained for the rest of the experiments were as follows. Real-time PCR was carried out in $20-\mu$ l reaction volumes using the $\mathrm{qPCR}$ core kit No ROX (Eurogentec). The reaction mixture contained molecular-grade water, $1 \times$ reaction buffer, $5 \mathrm{mM} \mathrm{MgCl}_{2}, 4 \times 0.2 \mathrm{mM}$ dNTPs, $0.05 \mu \mathrm{M}$ qPHAL-F, $0.3 \mu \mathrm{M}$ qPHAL-R, $0.05 \mu \mathrm{M}$ PHAL-P, $0.3 \mu \mathrm{M}$ each of the $18 \mathrm{~S}$-uni-F/-R primers, $0.1 \mu \mathrm{M} 18 \mathrm{~S}$-uni probe, $0.5 \mathrm{U}$ of Hotgoldstar, and $2 \mu \mathrm{l}$ of template DNA (0.8 to $20 \mathrm{ng}$ ). The realtime PCR cycling conditions included an initial denaturation step at $95^{\circ} \mathrm{C}$ for $10 \mathrm{~min}$ followed by 40 cycles of denaturation at $95^{\circ} \mathrm{C}$ for $10 \mathrm{~s}$ and annealing or elongation at $65^{\circ} \mathrm{C}$ for $45 \mathrm{~s}$.

All real-time PCR reactions were performed with a Rotor-Gene 6500 (Corbett Research, Mortlake, Australia) set with an autogain optimization for each channel, which was performed before the first fluorescence acquisition. The $\mathrm{Ct}$ value for each reaction was determined using the Rotor-Gene software, version 1.7.75, setting the threshold line at 0.02 .

Repeatability, reproducibility, and robustness. Repeatability and reproducibility were calculated for the duplex assay in the previously optimized qPCR conditions. Interassay coefficient of variation (CV\% based on mean $\mathrm{Ct}$ values) was assessed with a range of standard DNA samples with low target concentrations

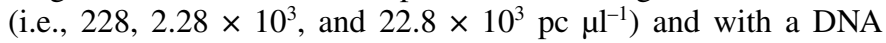
extract from a naturally infected seed sample (02 FU) (Table 2). Interassay $\mathrm{CV}$ was calculated from 10 consecutive assays run over a 4-week period with two different operators and using two different Rotorgene thermal cyclers. Intra-assay CV was computed with 10 replicates of the same set of DNA samples tested in the same run.

The robustness of a test was assessed by measuring its capacity to remain unaffected by small but deliberate variations in method parameters to provide an indication of its reliability during normal stage. The effects on sensitivity of $10 \%$ variation in the individual reaction volume or in the DNA template volume and variation of the hybridization temperature $\left(62\right.$ to $\left.67^{\circ} \mathrm{C}\right)$ were assessed testing 12 replicates of a standard DNA sample set at a concentration

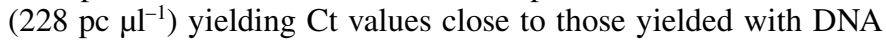
from seed samples containing $1 P$. halstedii-contaminated seed per 500 seeds (i.e., $\approx 30$ cycles).

\section{RESULTS}

Optimized qPCR conditions. In total, 48 primer/probe concentration ratios (testing $0.05,0.1,0.2$, or $0.3 \mu \mathrm{M}$ for each molecule) were tested for the qPHAL-F/-R/-P combination. Significantly lower mean Ct values $(n=432, F=17.7, P<0.001)$ were obtained with $0.05,0.3$, and $0.05 \mu \mathrm{M}$ final concentrations for qPHAL-F/-R/-P, respectively, and, thus, were retained for the rest of the experiments.

Modifications in the $\mathrm{MgCl}_{2}$ concentration of 4 to $6 \mathrm{mM}(n=$ 432, $F=17.7, P<0.001$ ) did not improve qPCR sensitivity; therefore, $5 \mathrm{mM} \mathrm{MgCl}$. was chosen because it is a standard in several qPCR commercial master mixes. The addition of BSA at the final concentration of $0.6 \mu \mathrm{g} \mu \mathrm{l}^{-1}$ did not significantly decrease the mean $\mathrm{Ct}$ values $(n=36, F=0.07, P=0.79$ ) compared with a master mix that did not contain BSA. Increasing the temperature from 60 to $65^{\circ} \mathrm{C}$ showed no significant effect on PCR sensitivity ( $n=27, F=0.11, P=0.89$ ); therefore, $65^{\circ} \mathrm{C}$ was retained to carry out the test under stringent conditions to reinforce specificity. There was no significant difference between the four denaturation-hybridization and DNA synthesis time patterns $(n=36, F=$ $0.81, P=0.49$ ) although, on average, the $10 / 45$-s pattern yielded lower $\mathrm{Ct}$ values. Using the best values retained for each parameter listed above, the four commercial qPCR mastermixes were compared and the use of the Eurogentec Core kit yielded significantly lower mean $\mathrm{Ct}$ values $(n=72, F=7.9, P=0.003)$.

Analytical specificity and sensitivity of the qPCR test. Length, secondary structure, intermolecular interaction, and Tm were first assessed on a panel of primer-probe combination to select the best candidates. A specific $P$. halstedii primer-hydrolysis probe (qPHAL-F/-R/-P) combination was successfully designed to be used in duplex with the internal DNA extraction control (18S uni-F/-R/-P) (Table 1). A BLAST search on GenBank with the qPHAL-F/-R/-P combination showed $100 \%$ in silico annealing to all the available orthologous sequences of $P$. halstedii, whereas no significant homology was found with any pseudogene or with unexpected target. The in vitro duplex qPCR test yielded positive results with all the $P$. halstedii DNA extracts, regardless of race, collection year, and geographical origin, thus supporting the inclusivity of the assay (Table 1). The assay did not cross-react with $1 \mathrm{ng}$ of DNA from any of the fungi commonly isolated from soil or sunflower seed, or with $1 \mathrm{ng}$ of DNA from any other Plasmopara spp., thus confirming the anticipated in silico analytical specificity (Table 1). DNA extracts from a series of field samples of $H$. annuus were tested by the duplex qPCR test and $P$. halstedii DNA was successfully detected in samples collected in fields where downy mildew symptoms were observed, with mean $\mathrm{Ct}$ values of 15.57 to 20.11 for seed samples and 10.12 to 18.20 for leaf samples (Table 2). In addition, the amplicons generated by qPCR with DNA from naturally infected samples $02 \mathrm{FU}, 14 \mathrm{KC} \mathrm{DM7,} 3 \mathrm{KC}$, and UKPOS 21023776 were sequenced and deposited to GenBank (accession numbers JQ724857, JQ724858, JQ724859, and JQ724860, respectively). Analysis of the sequences was carried out by BLAST on GenBank and all three sequences showed $100 \%$ identity with orthologous sequences from the voucher $P$. halstedii isolate H.V.926 (GenBank accession number EF553469), thus supporting the experimental specificity of the test with naturally infected samples. In contrast, no $\mathrm{Ct}$ value was obtained with DNA extracted from seed samples P.hal6 21023775/1 and P.hal7 $21023775 / 2$, although they were harvested in fields where symptoms of the disease were observed.

The monoplex qPCR test successfully yielded $100 \%$ repeatable positive results with down to 45.6 plasmid copies of target DNA per reaction tube which, therefore, was rated as the limit of detection of the test (Fig. 2), and the PCR efficiency was 0.91 . The qPCR test was tested in duplex, including the $18 \mathrm{~S}$ uni-F/-R/-P plant primers/probes at final concentrations of $0.1,0.1$, and $0.3 \mathrm{mM}$, respectively, with six replicates of the plasmid serial

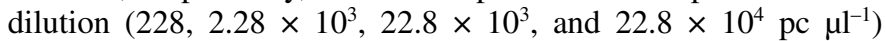

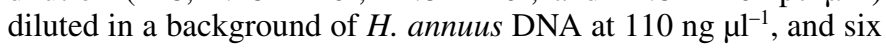
replicates of seed DNA samples 1 GB, 02 FU, 3 PSU7, 4 PR56, 5 MIX, and 6 GB*PR56. PCR efficiency was 1.20 for monoplex and decreased to 0.86 for duplex amplification (Fig. 3) but both systems still yielded positive mean $\mathrm{Ct}$ values and an exponential 
fluorescence curve with down to $228 \mathrm{pc}^{-1} \mathrm{l}^{-1}$ (i.e., 456 copies per PCR tube). The mean $\mathrm{Ct}$ values generated with DNA from the seed samples obtained by duplex or monoplex assay were not significantly different ( $n=72, F=1.020, P=0.320)$.

Optimized extraction of $\boldsymbol{P}$. halstedii nucleic acids. Following the DNA extraction optimization chart (Fig. 1), 360 DNA extracts were tested in triplicate with the optimized qPCR test, before or after an extra PVPP purification step and after a 10-fold dilution step. Overall ( $n=1944)$, significant sensitivity improvement (as inferred from $\mathrm{Ct}$ values) was observed for dry grinding (mean $\mathrm{Ct}$ $=30.64)$ versus TNE buffer grinding $(F=8.3, P=0.004)$, the use of Macherey-Nagel plant DNA extraction kit (mean $\mathrm{Ct}=27.12$ ) versus the others $(F=293, P<0.0001)$, and following 10 -fold dilution of the DNA template (mean $\mathrm{Ct}=30.23$ ) versus PVPP purification or no dilution $(F=9.2, P<0.0001)$ (Table 4$)$. The statistical significance was even improved when considering only the low infection levels corresponding to 5 infected seeds/1,000 seeds or to 1 infected seed/1,000 seeds (data not shown), thus supporting the combination of dry grinding-Macherey-Nagel plant DNA extraction kit-10-fold dilution of the DNA template as optimal. This combination enabled the detection of 1 infected seed/1,000 seeds in all replicates, with a mean $\mathrm{Ct}$ value of $30.9 \pm$ 1.5. Considering the standard curve observed for duplex PCR (Fig. 3), samples with less than 1 infected seed/1,000 seeds may yield positive results.

In contrast, the DNA concentration was significantly higher with other options (i.e., TNE buffer grinding) (mean $=183.8 \mathrm{ng}$ $\left.\mu^{-1}, F=1.9, P<0.0001\right)$, and use of Macherey-Nagel Food plant

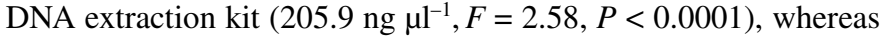
no significant difference was observed between grinding option
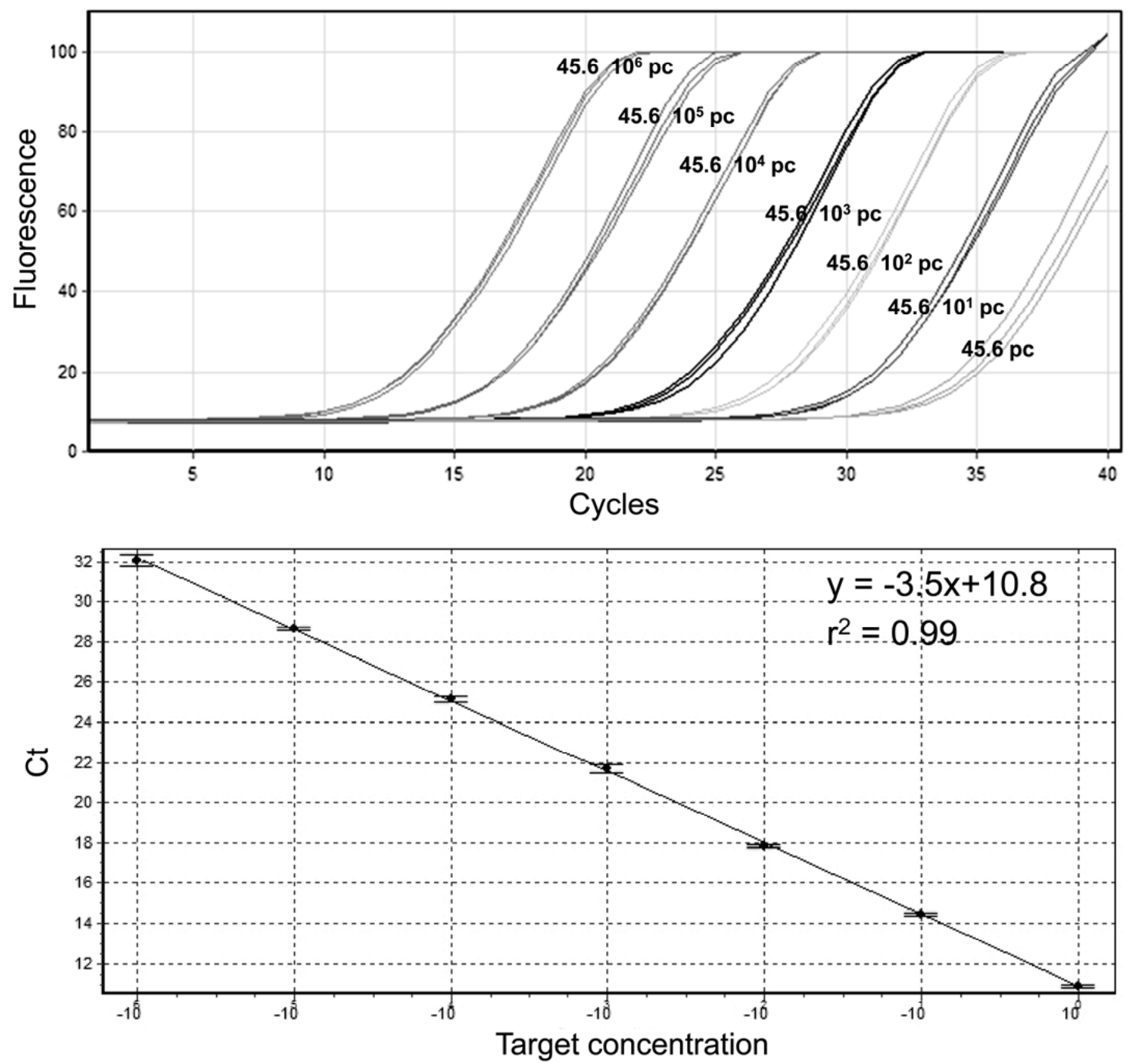

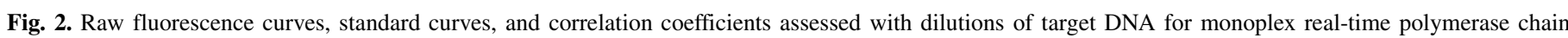

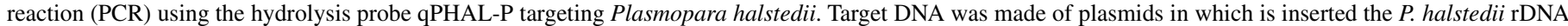

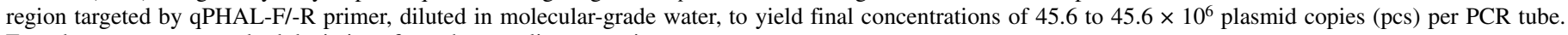
Error bars represent standard deviations from three replicate reactions. 
and DNA extraction kit regarding $\mathrm{A}_{280} / \mathrm{A}_{260}$ ratio (i.e., purity of the nucleic acids) (Table 4).

Based on mean $\mathrm{Ct}$ values, the three subsamples of the seed samples $(n=12)$ from which DNA was extracted following the best DNA extraction combination (dry grinding-Macherey-Nagel plant DNA extraction kit-10-fold dilution of the DNA template) were compared by Kruskal-Wallis one-way ANOVA, to test whether subsamples originate from the same distribution. For 7 of 12 seed samples, there was no statistical difference between mean $\mathrm{Ct}$ values obtained with DNA from the three subsamples $(P<$ 0.05 for each, mean $\mathrm{Ct}$ difference of 0.32 to 0.98 ), meaning that the ground sample was homogeneous. In contrast, significant differences between mean $\mathrm{Ct}$ values were observed with DNA from the three subsamples for the five other seed samples $(P>$ 0.05 for each, mean $\mathrm{Ct}$ difference of 0.89 to 3.40). Because the DNA extraction procedure was standardized, these slight differences probably arose from insufficiently homogenized $P$. halstedii biomass in the powder. Based on mean $\mathrm{Ct}$ values, homogenous or heterogeneous subsamples were observed regardless of the level of contamination ( 1 to 20 contaminated seed/1,000 seeds). Nevertheless, from a statutory point of view, all 12 samples would have undoubtedly been positive because the mean $\mathrm{Ct}$ values ranged from 23.49 for samples with 20 contaminated seeds/ 1,000 seeds to 31.09 for samples with 1 contaminated seed/1,000 seeds.

Performance criteria. For low DNA target concentration as well as for DNA from a naturally $P$. halstedii-infected seed sample, both the interassay and intra-assay CVs were low: 1.52 to 4.04 and 0.45 to $1.98 \%$, respectively (Table 5). The robustness of the tool was assessed with target DNA template concentrations close to the limit of detection (Table 6). The results of the duplex real-time PCR test were not significantly affected by a deliberate $\pm 10 \%$ variation of the reaction volume $(F=2.59, P=0.09)$. Likewise, increasing or decreasing the volume of DNA template by $10 \%$ did not significantly affect the mean $\mathrm{Ct}$ value $(F=0.50$, $P=0.61)$. However, using a $67^{\circ} \mathrm{C}$ hybridization and polymerizetion temperature significantly increased the mean $\mathrm{Ct}$ values $(F=$
$115, P<0.0001)$, whereas no difference was observed between 62 and $65^{\circ} \mathrm{C}$. The mean $\mathrm{Ct}$ value for $67^{\circ} \mathrm{C}$ was increased by 2.2 , in comparison with the hybridization and polymerization temperature recommended by this study (i.e., $65^{\circ} \mathrm{C}$ ).

\section{DISCUSSION}

The implementation of strict quarantine measures regarding the trade of $H$. annuus seeds relies upon the availability of a reliable detection tool. The zero-tolerance policy implies that the tool must be sensitive to detect very low levels of pathogen infestation in seed, because a single infected seed may potentially introduce the disease and initiate an epidemic. Introduction of new and aggressive genotypes of $P$. halstedii that are also potentially tolerant to the fungicides can have disastrous economic impact on

TABLE 4. Mean cycle threshold (Ct) values, quantity of total DNA yield, and DNA purity for the different parameters of the DNA extraction process ${ }^{\mathrm{x}}$

\begin{tabular}{lccc}
\hline Parameter $^{\mathrm{y}}$ & $\begin{array}{c}\text { Mean Ct } \\
\text { value }\end{array}$ & $\begin{array}{c}\text { Total DNA } \\
\text { yield }(\mathrm{ng} / \mu \mathrm{l})\end{array}$ & $\mathrm{A}_{260} / \mathrm{A}_{280} \mathrm{z}$ \\
\hline Grinding & & & \\
Dry & $30.64 \mathrm{a}$ & $65.8 \mathrm{a}$ & $1.719 \mathrm{a}$ \\
$\quad$ TNE buffer & $31.42 \mathrm{~b}$ & $183.8 \mathrm{~b}$ & $1.715 \mathrm{a}$ \\
Extraction kit & & & \\
$\quad$ Macherey-Nagel Plant & $27.12 \mathrm{a}$ & $112.2 \mathrm{~b}$ & $1.753 \mathrm{~b}$ \\
Macherey-Nagel Food & $36.25 \mathrm{c}$ & $205.9 \mathrm{c}$ & $1.794 \mathrm{~b}$ \\
Qiagen Plant & $30.49 \mathrm{~b}$ & $139.2 \mathrm{~b}$ & $1.817 \mathrm{~b}$ \\
Invitrogen Purelink & $30.24 \mathrm{~b}$ & $14.8 \mathrm{a}$ & $1.503 \mathrm{a}$ \\
DNA treatment & & & \\
Dilution to the 10th & $30.23 \mathrm{a}$ & n.d. & n.d. \\
No dilution & $31.28 \mathrm{~b}$ & $124.8 \mathrm{a}$ & 1.721 \\
PVPP spin column & $31.60 \mathrm{~b}$ & $7.4 \mathrm{~b}$ & n.r. \\
\hline
\end{tabular}

${ }_{\mathrm{x}}$ Numbers followed by the same letter are not significantly different according to Fisher's Least significant difference; n.d. $=$ not determined and n.r. $=$ no reliable measurement could be done because of interaction with remnant PVPP particles.

y $\mathrm{TNE}=$ Tris-NaCl-EDTA and PVPP $=$ polyvinyl-polypyrrolidone.

${ }^{z}$ Ratio of absorbance at $260 / 280 \mathrm{~nm}$.

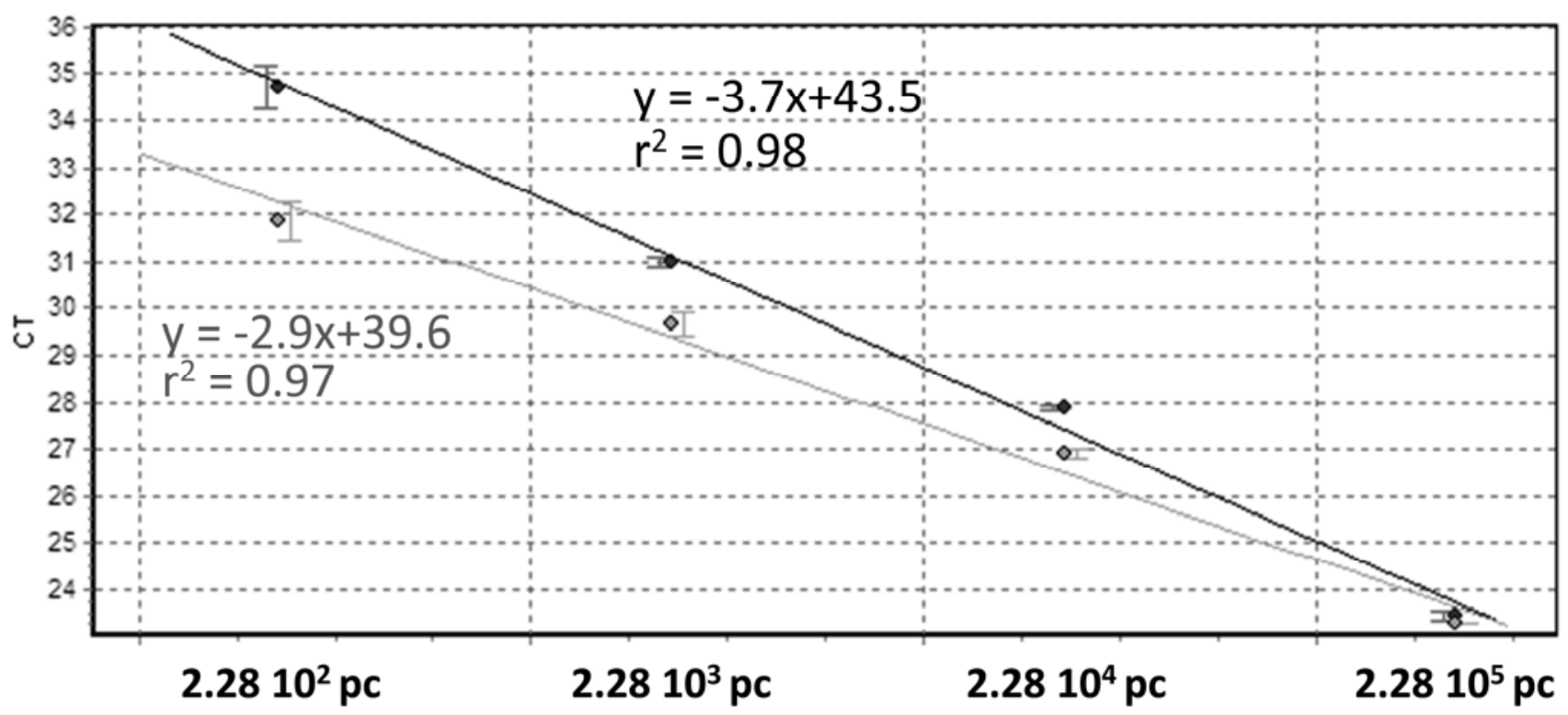

Final target concentration per PCR tube

Fig. 3. Standard curves and correlation coefficients assessed with dilution of target DNA for monoplex (qPHAL-P, gray line) and duplex (qPHAL-P + 18S uni-P, black line) real-time polymerase chain reaction (PCR). Target DNA was made of plasmids in which is inserted the Plasmopara halstedii rDNA region targeted by qPHAL-F/-R primer, diluted in a background of Helianthus annuus seed DNA, to yield final concentrations of $45.6 \times 10^{1}$ to $45.6 \times 10^{6}$ plasmid copies (pcs) per PCR tube. Error bars represent standard deviations from six replicate reactions. 
the crop and the growers. The real-time detection tool developed in this study targets a region in the rDNA specific for $P$. halstedii which is strictly conserved among isolates of $P$. halstedii, regardless of their genotype, geographical origin, and fungicide tolerance pattern. The primer-probe combination did not cross-react with a high quantity of DNA from non-target organisms, including closely related species, fungal taxa commonly encountered inside or outside $H$. annuus seeds, or in soil.

The global sensitivity of a qPCR test relies on both the quality of the DNA template and the efficiency of the PCR itself. The first step followed in this study was to optimize the duplex qPCR parameters to maximize the analytical sensitivity, without compromising the specificity. Despite the slight decrease in PCR efficiency, no significant effect on sensitivity was observed between the assay run in duplex or in monoplex. This was particularly important because a target of potentially low abundance ( $P$. halstedii DNA) is co-amplified with a highly abundant target (H. annuus DNA). Other PCR parameters such as the forward primer/reverse primer/probe ratio and the brand of qPCR mastermix were proven to statistically improve the sensitivity of the test. Surprisingly, the lowest concentration for the hydrolysis probe (i.e., $0.05 \mathrm{mM}$ ) proved to be the best one regarding sensitivity. This will reduce the cost of the test and suggests that a low probe concentration may not be a problem for real-time assays, because the $\mathrm{Ct}$ value will have been generated well before the probe supply is exhausted. Based on these results, an optimized qPCR pattern and reaction mixture composition could be determined and used for the second part of the work aimed at improving the DNA extraction from sunflower seeds.

In the case of $P$. halstedii, the efficiency of the DNA extraction process is of paramount importance because the pathogen cannot be subcultured and biologically amplified to improve sensitivity of the test, as for another seedborne fungus, G. circinata (14). In addition, chemical compounds present in the seed, especially in the hull, may inhibit the PCR reaction (10) to either provide inconclusive or spurious results. A dry grinding followed by the use of a specific brand of commercial DNA extraction kit and a 10 -fold dilution of the DNA extract before qPCR testing yielded the lowest mean $\mathrm{Ct}$ value for the detection of the target. The lowest mean $\mathrm{Ct}$ values were not directly connected with the highest total DNA yield, because the finally retained DNA extraction protocol was statistically not the best one for this parameter.
The dry grinding method produces a sufficiently homogenized powder and a single subsample of this powder may be enough for analysis. Finally, the test developed in this study successfully yielded positive results with down to 45 copies of target DNA per PCR tube. Combined with an optimized DNA extraction protocol, this assay detected less than a single $P$. halstedii-contaminated seed per 1,000 seeds, whereas the detection threshold previously determined for the conventional PCR test was estimated to be five $P$. halstedii-contaminated seeds $/ 500$ seeds (15). In spite of the improvement in terms of sensitivity, $P$. halstedii DNA was not detected in all the samples collected in fields where downy mildew symptoms were observed. This may be due to the uneven distribution of the pathogen in the harvest or a contamination level below the detection threshold of the test. Another explanation would be that $P$. halstedii can be absent in seeds from capitula showing downy mildew symptoms, as already shown by Meliala by microscopic observation (17) and Ioos et al. by conventional PCR (15).

In parallel with the development and optimization of the realtime PCR detection of $P$. halstedii, a thorough validation process has been followed to provide data about the performance of the protocol in the context of routine analysis. For routine analysis, a plant pest diagnosis test should meet minimum performance criteria, and this validation process was in line with the requirements of the EPPO standard PM 7/98 (4). The test was demonstrably repeatable and reproducible. In practice, volume and temperature variations did not qualitatively affect the results because, based on the mean $\mathrm{Ct}$ values, the results would have been rated as positive for the target, even when target concentrations were close to the limit of detection. From a practical point of view, these results demonstrated that the qPCR test was robust and the results were consistent even with slight pipetting errors or temperature drift in the thermal cycler. Finally, from a biosecurity perspective, this method is also particularly well adapted to routine analysis because it does not require subculturing a potentially harmful organism or propagating it on plant tissue. Because the detection tool developed in this work is DNA based, it will not make the distinction between viable or infectious material and nonviable or noninfectious material. However, the presence of pathogen DNA, even if associated with nonviable propagules, may indicate that viable a inoculum resides elsewhere in the lot being tested. Consequently, for a pathogen subject to quarantine

TABLE 5. Inter- and intra-assay coefficients of variation (CVs) based on mean cycle threshold values calculated for the duplex $P$. halstedii quantitative polymerase chain reaction $(\mathrm{PCR})$ assay

\begin{tabular}{|c|c|c|c|}
\hline \multirow[b]{2}{*}{ Target } & \multirow[b]{2}{*}{ Target concentration ${ }^{\mathrm{x}}$} & \multicolumn{2}{|c|}{$\mathrm{CV}(\%)$} \\
\hline & & Intra-assay & Interassay \\
\hline \multirow[t]{2}{*}{ Plasmopara halstedii $\mathrm{qPHAL}-\mathrm{F} / \mathrm{R}$ PCR product } & $2.26 \times 10^{4}$ & 0.45 & 2.21 \\
\hline & $2.26 \times 10^{3}$ & 0.52 & 1.52 \\
\hline P. halstedii DNA & n.d. ${ }^{z}$ & 1.74 & 4.04 \\
\hline
\end{tabular}

${ }^{\mathrm{x}}$ Number of plasmid copies in the PCR tube, in which was inserted the qPHAL-F/-R region, diluted in a background of Helianthus annuus DNA.

$\mathrm{y}$ This concentration was determined as 10 times the limit of detection of the test.

${ }^{z}$ Total DNA extract from a naturally infected $H$. annuиs seed sample (02 FU).

TABLE 6. Assessment of the robustness of the duplex real-time polymerase chain reaction (PCR) assay using 10\%-variable quantity of DNA target, 10\% -variable reaction volumes in individual PCR tubes, and $2^{\circ} \mathrm{C}$-variable hybridization/polymerization temperature tested with 12 replicates of a DNA template set at 10 times the limit of detection of the test (i.e., 452 plasmid copies per PCR tube)

\begin{tabular}{|c|c|c|c|}
\hline Parameter & & Mean $\mathrm{Ct}( \pm \mathrm{SD})^{\mathrm{z}}$ & \\
\hline \multirow[t]{2}{*}{ Individual reaction volume } & $18 \mu 1$ & $20 \mu 1$ & $22 \mu 1$ \\
\hline & $28.81 \pm 0.46 \mathrm{a}$ & $29.22 \pm 0.46 \mathrm{a}$ & $29.22 \pm 0.59 a$ \\
\hline Volume of DNA template & $1.8 \mu \mathrm{l}$ & $2.0 \mu \mathrm{l}$ & $2.2 \mu \mathrm{l}$ \\
\hline \multirow[t]{2}{*}{ Hybridization temperature } & $63^{\circ} \mathrm{C}$ & $65^{\circ} \mathrm{C}$ & $67^{\circ} \mathrm{C}$ \\
\hline & $29.59 \pm 0.42 \mathrm{a}$ & $29.94 \pm 0.54 \mathrm{a}$ & $32.16 \pm 0.36 \mathrm{~b}$ \\
\hline
\end{tabular}

${ }^{\mathrm{z}}$ Numbers followed by the same letter are not significantly different according to Fisher's least significant difference. 
restrictions, it is appropriate to consider such results as positive, even if viability has not been confirmed.

\section{ACKNOWLEDGMENTS}

This research was supported financially by the French Agency for Food, Environmental and Occupational Health \& Safety (ANSES). We thank T. Gulya and M. Ramsett (United States Department of Agriculture) for their provision of positive material and two anonymous reviewers for their very useful comments on a previous version of this manuscript.

\section{LITERATURE CITED}

1. Anonymous. 2000. Council Directive 2000/29/EC of 8 May 2000 on protective measures against the introduction into the Community of organisms harmful to plants or plant products and against their spread within the Community. O.J.L 169, 10.7.2000:1.

2. Anonymous. 2008. Commission Directive 2008/61/EC of 17 June 2008 establishing the conditions under which certain harmful organisms, plants, plant products and other objects listed in Annexes I to $\mathrm{V}$ to Council Directive 2000/29/EC may be introduced into or moved within the Community or certain protected zones thereof, for trial or scientific purposes and for work on varietal selections. O. J. o. t. E. Union, ed. L157.

3. Anonymous. 2008. Plasmopara halstedii. Bull. OEPP/EPPO Bull. 38:343-348.

4. Anonymous. 2010. PM 7/98 (1): Specific requirements for laboratories preparing accreditation for a plant pest diagnostic activity. EPPO Bull. 40:5-22.

5. Boonham, N., Glover, R., Tomlinson, J., and Mumford, R. 2008. Exploiting generic platform technologies for the detection and identification of plant pathogens. Eur. J. Plant Biol. 121:355-363.

6. Breslauer, K. J., Frank, R., Blöcker, H., and Marky, L. A. 1986. Predicting DNA duplex stability from the base sequence. Proc. Natl. Acad. Sci. USA 83:3746-3750.

7. Bustin, S. 2000. Absolute quantification of mRNA using real-time reverse transcription polymerase chain reaction assays. J. Mol. Endocrinol. 25:169-193.

8. Constantinescu, O., and Thines, M. 2010. Plasmopara halstedii is absent from Australia and New Zealand. Polish Bot. J. 55:293-298.

9. Cullen, D. W., and Hirsch, P. R. 1998. Simple and rapid method for direct extraction of microbial DNA from soil for PCR. Soil. Biol. Biochem. 30:983-993.

10. Demeke, T., and Jenkins, G. 2010. Influence of DNA extraction methods, PCR inhibitors and quantification methods on real-time PCR assay of biotechnology-derived traits. Anal. Bioanal. Chem. 396:1977-1990.

11. Gulya, T. J. 2007. Distribution of Plasmopara halstedii races around the world. Adv. Downy Mildew Res. 3:121-134.

12. Ioos, R., Fabre, B., Saurat, C., Fourrier, C., Frey, P., and Marçais, B. 2010.
Development, comparison, and validation of real-time and conventional PCR tools for the detection of the fungal pathogens causing brown spot and red band needle blights of pine. Phytopathology 100:105-114.

13. Ioos, R., and Fourrier, C. 2011. Validation and accreditation of a duplex real-time PCR test for reliable in planta detection of Chalara fraxinea. EPPO Bull. 41:21-26.

14. Ioos, R., Fourrier, C., Iancu, G., and Gordon, T. R. 2009. Sensitive detection of Fusarium circinatum in pine seed by combining an enrichment procedure with a real-time polymerase chain reaction using dual-labeled probe chemistry. Phytopathology 99:582-590.

15. Ioos, R., Laugustin, L., Rose, S., Tourvieille, J., and Tourvieille de Labrouhe, D. 2007. Development of a PCR test to detect the downy mildew causal agent Plasmopara halstedii in sunflower seeds. Plant Pathol. 56:209-218.

16. Leppik, E. E. 1962. Distribution of downy mildew and some other seedborne pathogens on sunflower. Bull. FAO 10:126-129.

17. Meliala, C. 2001. Biology of Plasmopara halstedii (Farl.) Berl. et De Toni, causal agent of downy mildew on sunflower (Helianthus annuиs). Ph.D. thesis, Blaise Pascal University, Clermont-Ferrand, France.

18. Riethmüller, A., Voglmayr, H., Göker, M., Weiß, M., and Oberwinkler, F. 2002. Phylogenetic relationships of the downy mildews (Peronosporales) and related groups based on nuclear large subunit ribosomal DNA sequences. Mycologia 94:834-849.

19. Tan, M., Brennan, J. P., Wright, D., and Murray, G. M. 2010. An enhanced protocol for the quarantine detection of Tilletia indica and economic comparison with the current standard. Australas. Plant Pathol. 39:334-342.

20. Tourvieille de Labrouhe, D., Gulya, T. J., Masirevic, S., Penaud, A., Rachid, K., and Viranyi, F. 2000. New nomenclature of races of Plasmopara halstedii (sunflower downy mildew). Pages 61-66 in: 15th Int. Sunflower Conf. Toulouse, France.

21. van Brouwershaven, I. R., Bruil, M. L., van Leeuwen, G. C. M., and Kox, L. F. F. 2010. A real-time (TaqMan) PCR assay to differentiate Monilinia fructicola from other brown rot fungi of fruit crops. Plant Pathol. 59:548555.

22. van Gent-Pelzer, M. P. E., van Brouwershaven, I. R., Kox, L. F. F., and Bonants, P. J. M. 2007. A TaqMan PCR method for routine diagnosis of the quarantine fungus Guignardia citricarpa on citrus fruit. Journal of Phytopathology 155:357-363.

23. Viranyi, F., and Spring, O. 2010. Advances in sunflower downy mildew research. Eur. J. Plant Biol.:1-14.

24. Voglmayr, H., and Constantinescu, O. 2008. Revision and reclassification of three Plasmopara species based on morphological and molecular phylogenetic data. Mycol. Res. 112:487-501.

25. White, T. J., Bruns, T., Lee, S., and Taylor, J. 1990. Amplification and direct sequencing of fungal ribosomal RNA genes for phylogenetics. Pages 315-322 in: PCR Protocols: A Guide to Method and Applications. M. A. Innis, D. H. Gelfand, J. J. Sninsky, and T. J. White, eds. Academic Press, New York.

26. Wilson, I. 1997. Inhibition and facilitation of nucleic acid amplification. Appl. Environ. Microbiol. 63:3741-3751. 